\title{
Cotrimoxazole-induced hypoglycemia in an HIV-infected patient
}

\author{
Christine A Hughes PharmD ${ }^{1}$, Constance L Chik MD PhD FRCPC ${ }^{2}$, Geoffrey D Taylor MD FRCPC ${ }^{3}$
}

\begin{abstract}
CA Hughes, CL Chik, GD Taylor. Cotrimoxazole-induced hypoglycemia in an HIV-infected patient. Can J Infect Dis $2001 ; 12(5): 314-316$.

A case of cotrimoxazole-induced hypoglycemia is described in a male patient infected with HIV. Ten days after initiating high dose cotrimoxazole for suspected Pneumocystis carinii pneumonia, the patient developed neuroglycopenic symptoms and diaphoresis. Blood glucose levels were repeatedly low, with elevated insulin and C-peptide levels despite multiple intravenous bolus doses and infusions of dextrose. Hypoglycemia resolved after approximately $36 \mathrm{~h}$ of treatment with dextrose and discontinuation of cotrimoxazole. A review of reported cases of hypoglycemia associated with cotrimoxazole is provided, including information about onset, risk factors and possible mechanism.
\end{abstract}

Key Words: Cotrimoxazole; HIV; Hypoglycemia

\section{Hypoglycémie causée par le cotrimoxazole chez un patient porteur du VIH}

RÉSUMÉ : Voici un cas d'hypoglycémie causée par le cotrimoxazole chez un homme porteur du VIH. Dix jours après avoir commencé un traitement au cotrimoxazole à fortes doses pour une pneumonie présumée à Pneumocystis carinii, le patient a manifesté des symptômes neuroglycopéniques et de la diaphorèse. La glycémie se maintenait basse tandis que les concentrations d'insuline et de peptide C restaient élevées malgré l'administration de plusieurs bolus intraveineux et l'installation de perfusions de dextrose. L'hypoglycémie a fini par céder après $36 \mathrm{~h}$ environ de traitement au dextrose et l'interruption du cotrimoxazole. Suit une revue des cas déclarés d'hypoglycémie associée au cotrimoxazole; on y traite notamment de l'apparition du trouble, des facteurs de risque et des mécanismes possibles.

C otrimoxazole (trimethoprim/sulfamethoxazole) is the therapy of choice for the treatment of Pneumocystis carinii pneumonia (1). Advantages of cotrimoxazole include excellent tissue penetration, rapid clinical response and oral bioavailability that is comparable with the parenteral form $(1,2)$. Unfortunately, many patients with AIDS experience adverse reactions to cotrimoxazole, often requiring discontinuation of therapy (3). Hypoglycemia is rarely encountered with the use of cotrimoxazole (4-14). We report a case of hypoglycemia as a result of cotrimoxazole therapy in an HIVinfected male patient.

\section{CASE PRESENTATION}

A 41-year-old male patient was referred for evaluation of pneumonia. The patient was recently found to be HIV-positive, and had a history of weight loss, night sweats and cough over the previous several months. At the time of diagnosis, the viral load was 330,000 copies/mL (HIV Monitor, Roche Diagnostic Specimens, USA) and the CD4 count was $80 \times 10^{6} / \mathrm{L}$. Past medical history included hepatitis C. There was no history of diabetes. Medications before admission were diazepam, ranitidine, trazodone, propoxyphene and acetaminophen.

\footnotetext{
${ }^{1}$ Faculty of Pharmacy and Pharmaceutical Sciences, ${ }^{2}$ Division of Endocrinology and Metabolism and ${ }^{3}$ Division of Infectious Diseases, University of Alberta, Edmonton, Alberta

Correspondence and reprints: Dr CA Hughes, Faculty of Pharmacy and Pharmaceutical Sciences, 3118 Dentistry/Pharmacy Centre,

University of Alberta, Edmonton, Alberta T6G 2N8. Telephone 780-492-5903,fax 780-492-1217, e-mail christine.hughes@ualberta.ca Received for publication August 9, 2000. Accepted January 29, 2001
} 
On presentation, the following statistics were recorded: oxygen saturation $94 \%$ on room air, blood pressure $100 / 60 \mathrm{mmHg}$, heart rate 80 beats/min, respiratory rate 20 breaths/min and temperature $36.3^{\circ} \mathrm{C}$. Physical examination revealed a thin male with bilateral basal crackles, oral candidiasis and hairy leukoplakia. Chest x-ray revealed focal areas of increased opacity in the right middle and left lingular regions. Laboratory concentrations were as follows: normal hemoglobin, white blood cell count and electrolytes; serum creatinine $67 \mu \mathrm{mol} / \mathrm{L}$; blood urea nitrogen $4.7 \mathrm{mmol} / \mathrm{L}$; random serum glucose $4.5 \mathrm{mmol} / \mathrm{L}$; and lactate dehydrogenase $203 \mathrm{U} / \mathrm{L}$. A bronchoscopy was performed. The patient was initiated on cotrimoxazole double strength (trimethoprim $160 \mathrm{mg} / \mathrm{sul}$ famethoxazole $800 \mathrm{mg}$ ), two tablets by mouth every $6 \mathrm{~h}$.

On review four days later, his clinical status was unchanged. The bronchoalveolar lavage was negative for $P$ carinii, bacterial growth, atypical pathogens, acid-fast bacilli and fungi. Levofloxacin $500 \mathrm{mg}$ by mouth daily was added to cotrimoxazole. The patient was transferred to a rural hospital near his home. His previous medications were continued during his hospitalization.

Six days later, the patient was noted to be shaky and disoriented. Later, he was found to be diaphoretic and unresponsive. A glucometer reading indicated a blood glucose of $1 \mathrm{mmol} / \mathrm{L}$. He was given a $25 \mathrm{~g}$ bolus of dextrose $50 \%$. Ten minutes later, he was awake and oriented, and the result of a repeat glucose test was $9 \mathrm{mmol} / \mathrm{L}$. Cotrimoxazole and levofloxacin were discontinued. The next morning, the patient vomited and became unresponsive. The blood glucose concentration was again found to be 'low', and he was given another bolus of dextrose $50 \%$. A repeat glucose test $15 \mathrm{~min}$ later yielded a result of $14 \mathrm{mmol} / \mathrm{L}$. The patient was prepared for transfer to the Northern Alberta HIV Program, University of Alberta Hospital (Edmonton, Alberta) for his follow-up appointment.

En route to the clinic, he became combative. Blood glucose concentration was $1 \mathrm{mmol} / \mathrm{L}$. He was given two boluses of dextrose $50 \%$. On arrival to the outpatient clinic, the patient was semiconscious. The blood glucose level was $1 \mathrm{mmol} / \mathrm{L}$. He was given additional boluses of dextrose $50 \%$ and was started on an infusion. A repeat blood glucose 10 min later was $10.9 \mathrm{mmol} / \mathrm{L}$.

On admission, laboratory data were as follows: $\mathrm{pH} 7.36$, partial pressure of arterial oxygen $87 \mathrm{mmHg}$, partial pressure of carbon dioxide in arterial gas $36 \mathrm{mmHg}$, oxygen saturation 96\%, hemoglobin count $118 \mathrm{~g} / \mathrm{L}$, white blood cell count $9.1 \times 10^{9} / \mathrm{L}$, alanine aminotransferase concentration $71 \mathrm{U} / \mathrm{L}$, creatinine concentration $120 \mu \mathrm{mol} / \mathrm{L}$, albumin $38 \mathrm{~g} / \mathrm{L}$. His serum cortisol level was $398 \mathrm{nmol} / \mathrm{L}$ (normal range 85 to $460 \mathrm{nmol} / \mathrm{L}$ ), C-peptide level was $4.2 \mathrm{nmol} / \mathrm{L}$ (normal range 0.3 to $1.32 \mathrm{nmol} / \mathrm{L}$ ) and insulin level was $30.2 \mathrm{mU} / \mathrm{L}$ (normal range 5 to $20 \mathrm{mU} / \mathrm{L}$ ). A repeat chest x-ray showed partial resolution of patchy opacities, and an abdominal ultrasound showed no evidence of a pancreatic lesion. Over the first hospital day, he required repeated boluses of $50 \%$ dextrose and increasing concentrations of dextrose infusions, reaching
$200 \mathrm{~mL} / \mathrm{h}$ of D10W to maintain adequate blood glucose levels. Medications were held at the time of admission.

The next day, the infusion was held for additional investigation of his hypoglycemia, and blood glucose decreased to $2.5 \mathrm{mmol} / \mathrm{L}$. There was an elevated C-peptide concentration ( $2.3 \mathrm{nmol} / \mathrm{L})$; however, human growth hormone, adrenocorticotropic hormone, serum cortisol, insulin-like growth factor and insulin levels were all within the normal range. The infusion was restarted, and blood glucose remained in the normal range for the rest of the admission. The next day, the dextrose infusion was discontinued. The patient was discharged home the following day on levofloxacin $500 \mathrm{mg}$ daily and dapsone $50 \mathrm{mg}$ daily. The patient was seen two weeks later for treatment of his HIV disease. Unfortunately, the patient died soon afterwards due to causes unrelated to his HIV disease.

\section{DISCUSSION}

Hypoglycemia is a clinical syndrome with numerous etiologies characterized by low levels of plasma glucose, which eventually leads to neuroglycopenia $(15,16)$. Several medications may induce or exacerbate hypoglycemia, including salicylates, acetaminophen, beta-blockers, pentamidine, disopyramide, quinine, ethanol and propoxyphene (17). Cotrimoxazole has also been reported to cause hypoglycemia (4-14). The majority of case reports of cotrimoxazole-induced hypoglycemia have occurred in elderly patients or patients with renal failure $(4-7,9-12,14)$. The mean onset of hypoglycemia in these cases was seven days, and symptoms persisted despite appropriate treatment for $8 \mathrm{~h}$ to more than $48 \mathrm{~h}$ (12).

There is only one previous case report in the literature of hypoglycemia associated with cotrimoxazole in an HIVinfected patient. Schattner et al (8) reported a 34-year-old HIV-infected male patient who received cotrimoxazole intravenously for $P$ carinii (dose not specified). The patient had normal renal function but had underlying hepatic disease and AIDS-associated weight loss. Six days after the initiation of cotrimoxazole, the patient's glucose level was $1.1 \mathrm{mmol} / \mathrm{L}$, insulin level was $12 \mathrm{mU} / \mathrm{L}$, and C-peptide and cortisol levels were both elevated. Intravenous dextrose rapidly improved his neurological state, and there were no further episodes of hypoglycemia over several months. Oral cotrimoxazole was initiated, and the patient's fever settled and pulmonary status improved. The authors suggest that high drug levels were likely, and hepatitis contributed to this. Liver disease also may have exacerbated the hypoglycemia by impairing glycogenolysis and gluconeogenesis (8).

In our patient, hypoglycemia developed 10 days after initiating high dose cotrimoxazole and persisted for longer than $24 \mathrm{~h}$. The patient did not have severe liver disease or underlying renal dysfunction. There was also no evidence of adrenal or growth hormone deficiency. However, insulin and C-peptide levels were high, suggesting increased insulin secretion as a cause of his hypoglycemia. As well, the patient was receiving acetaminophen and propoxyphene before the initiation of cotrimoxazole, both of which have been reported to cause hypoglycemia (17). However, the patient did not 
experience any hypoglycemic episodes with these agents before or after the discontinuation of cotrimoxazole. Our patient did have a recent history of significant weight loss and was likely not eating well due to the concurrent illness. Thus, poor dietary intake may have been a contributing factor in this case.

The mechanism of hypoglycemia associated with sulfamethoxazole is likely due to its structural similarity to the sulfonylureas $(7,18)$. It is hypothesized that sulfamethoxazole increases insulin secretion. This theory is supported by increased insulin and/or C-peptide levels in many of the case reports $(4,6,11)$ and in our patient. The occurrence of hypoglycemia appears to be dose-related. In two case reports, no further symptoms of hypoglycemia occurred when the dose of cotrimoxazole was adjusted for renal function $(6,12)$.

The present case report illustrates the importance of monitoring for signs and symptoms of low blood glucose when initiating therapy with high dose cotrimoxazole, even in younger patients without underlying risk factors such as renal or liver disease. Due to the increased prevalence of diabetes in HIV-infected patients receiving protease inhibitor therapy, close monitoring of blood glucose may be necessary, particularly in patients receiving sulfonylurea therapy. Prompt institution of intravenous dextrose is required to prevent seizures, coma and death. The decision to discontinue cotrimoxazole therapy depends on the patient; however, limited data suggest that some patients may be successfully rechallenged with a lower dose.

\section{REFERENCES}

1. Fishman JA. Treatment of infection due to Pneumocystis carinii. Antimicrob Agents Chemother 1998;42:1309-14.

2. Warren E, George S, You J, Kazanjian P. Advances in the treatment and prophylaxis of Pneumocystis carinii pneumonia. Pharmacotherapy 1997;17:900-16.

3. Gordin FM, Simon GL, Wofsy CB, Mills J. Adverse reactions to trimethoprim-sulfamethoxazole in patients with the acquired immunodeficiency syndrome. Ann Intern Med 1984;100:495-9.

4. Arem R, Garber AJ, Field JB. Sulfonamide-induced hypoglycemia in chronic renal failure. Arch Intern Med 1983;143:827-9.

5. Poretsky L, Moses AC. Hypoglycemia associated with trimethoprim/sulfamethoxazole therapy. Diabetes Care 1984;7:508-9.

6. Frankel MC, Leslie BR, Sax FL, Soave R. Trimethoprimsulfamethoxazole-related hypoglycemia in a patient with renal failure. N Y State J Med 1984;1:30-1.

7. Ryan DW, Oyston J. Sulphonylureas and hypoglycaemia. Br Med J (Clin Res Ed) 1988;296:1328.

8. Schattner A, Rimon E, Green L, Coslovsky R, Bentwich Z. Hypoglycaemia induced by co-trimoxazole in AIDS. Br Med J 1988;297:742.

9. McKnight JT, Gaskins GE, Pieroni RE, Machen GM. Severe hypoglycemia associated with trimethoprimsulfamethoxazole therapy. J Am Board Fam Pract 1988;1:143-5.

10. Mansoor GA, Nicholson GD. Hypoglycaemia in chronic renal failure. W I Med J 1992;41:41-2.

11. Johnson JA, Kappel JE, Sharif MN. Hypoglycemia secondary to trimethoprim/sulfamethoxazole administration in a renal transplant patient. Ann Pharmacother 1993;27:304-6.

12. Lee AJ, Maddix DS. Trimethoprim/sulfamethoxazole-induced hypoglycemia in a patient with acute renal failure. Ann Pharmacother 1997;31:727-32.

13. Hekimsoy Z, Biberoglu S, Comlekci, Tarhan O, Mermut C, Biberoglu K. Trimethoprim/sulphamethoxazole-induced hypoglycemia in a malnourished patient with severe infection. Eur J Endocrinol 1997;136:304-6.

14. Mathews WA, Manint JE, Kleiss J. Trimethoprimsulfamethoxazole-induced hypoglycemia as a cause of altered mental status in an elderly patient. J Am Board Fam Pract 2000;13:211-2.

15. Service FJ. Hypoglycemia. Endocrinol Metab Clin North Am 1997;26:937-51.

16. Service FJ. Hypoglycemic Disorders. N Engl J Med 1995;332:1144-52.

17. Pandit MK, Burke J, Gustafson AB, Minocha A, Peiris AN. Drug-induced disorders of glucose tolerance. Ann Intern Med 1993;118:529-39.

18. Williams JD. The Garrod Lecture: selective toxicity and concordant pharmacodynamics of antibiotics and other drugs. J Antimicrob Chemother 1993;35:721-37. 


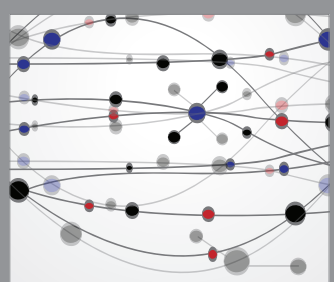

The Scientific World Journal
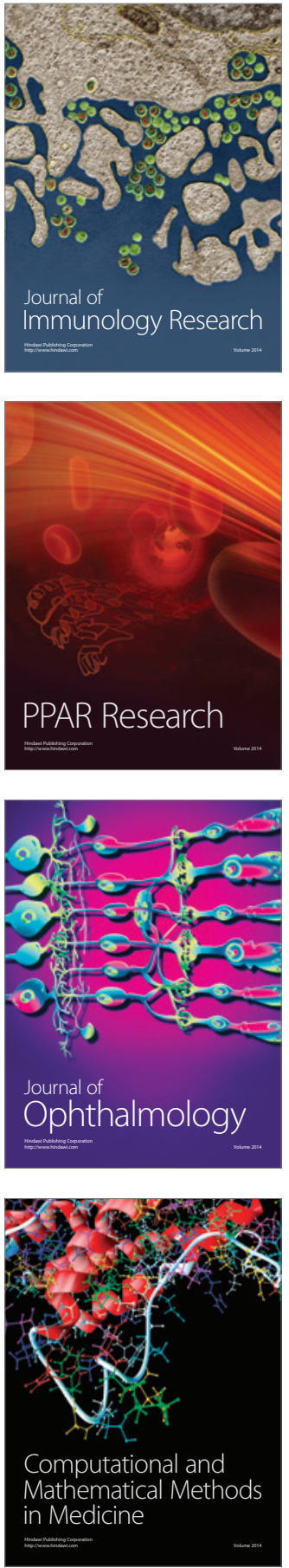

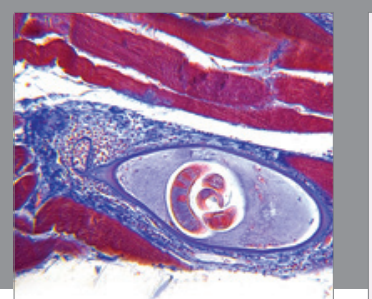

Gastroenterology Research and Practice

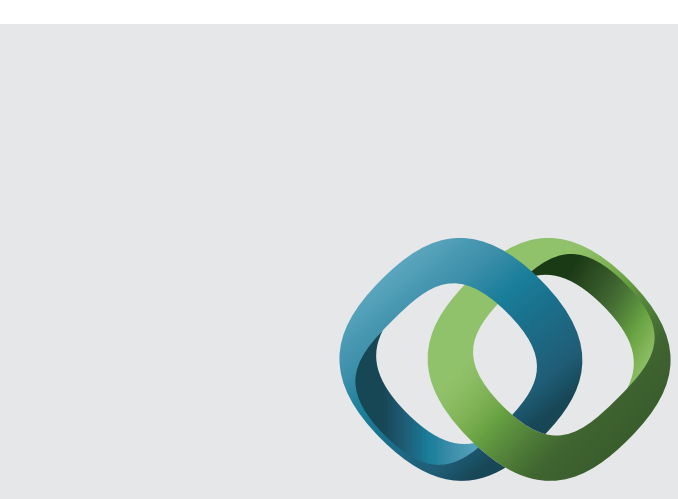

\section{Hindawi}

Submit your manuscripts at

http://www.hindawi.com
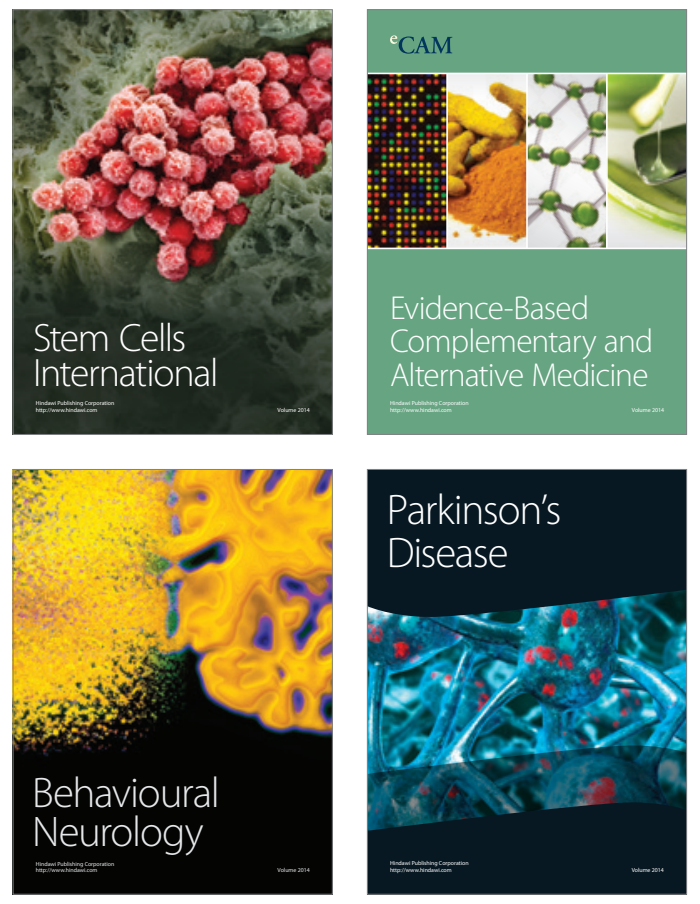
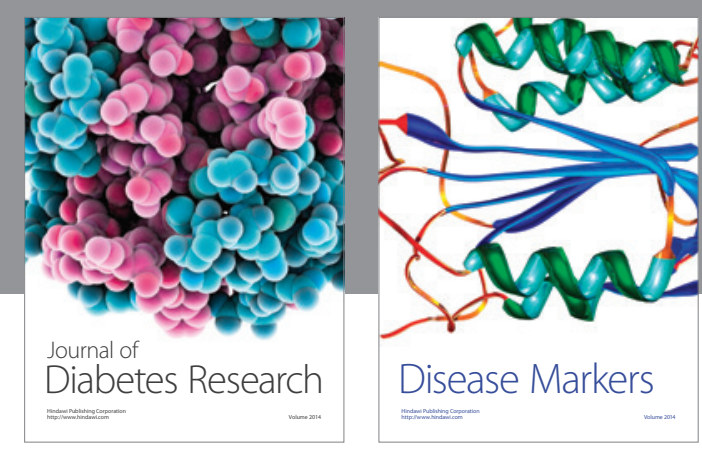

Disease Markers
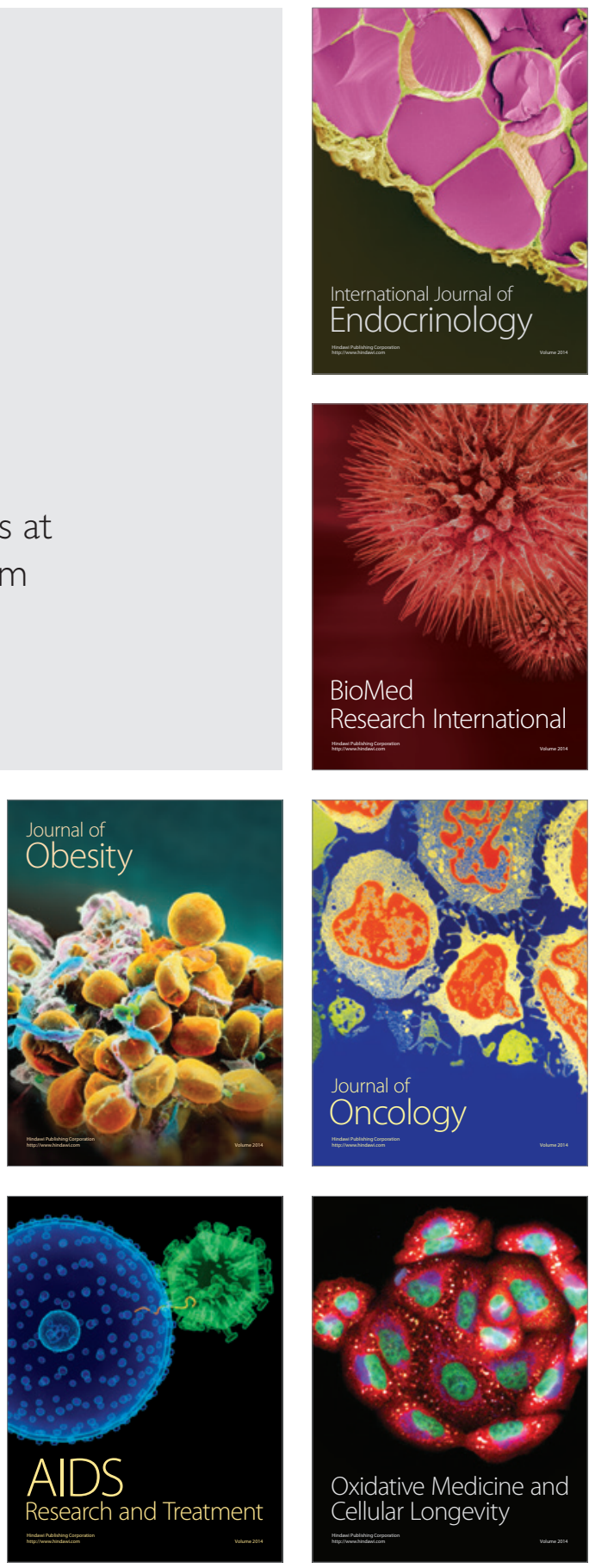